\title{
Establishing Individual Care Plans for Rehabilitation Patients: Traces of Self-Targeting in the Norwegian Universal Welfare State
}

\author{
Ivan Harsløf * \\ Department of Social Work, Child Welfare and Social Policy \\ Oslo Metropolitan University \\ Email: ivan.harslof@oslomet.no
}

\section{Mirela Slomic}

Department of Nursing and Health Promotion

Oslo Metropolitan University

Email: Mirela.Slomic@ hioa.no

\section{Ole Kristian Sandnes Håvold}

Department of Social Work, Child Welfare and Social Policy

Oslo Metropolitan University

Email: Ole.Havold@oslomet.no

${ }^{*}$ corresponding author

\begin{abstract}
Several countries have introduced devices for coordination of complicated individual cases across care, health and welfare services. This study examined one such device: the individual care plan (ICP), introduced in Norway in 2001 to enhance user involvement and coordination across sectors and service providers. Despite strong political imperatives, however, ICPs have remained significantly underused. To understand why, this study investigated the experiences with ICPs among staff in municipal coordinating units, tasked with organising rehabilitation efforts and caseworkers in local labour and welfare services. In focus groups, participants discussed the fictitious vignette of a patient with traumatic brain injury, a person clearly within the ICP target group. They praised ICPs for advancing the rehabilitation process but acknowledged that they were applied too rarely. Through abductive-retroductive recontextualisation, this study identified a practice of de-facto self-targeting: in some municipalities, patients had to request ICPs themselves. We argue that
\end{abstract}


this mechanism may have emerged from ambiguous propensities of rehabilitation, simultaneously emphasising needs and potentials, and ultimately from ambiguities in the Norwegian welfare model balancing universalism and local autonomy.

Keywords: Critical Realism, Individual Care Plan, Rehabilitation, Social Services, Service Universalism

\section{Introduction}

To tackle the growing challenge of coordination and to enhance capacity in care, health and welfare services, recent decades have seen several countries launching initiatives to strengthen collaboration among actors representing different branches and levels of government (Hanssen, Helgesen \& Vabo, 2018; Renner et al. 2018; Rudkjøbing, Strandberg-Larsen, Vrangbæk, Andersen \& Krasnik, 2014). At the strategic level, agencies have entered into alliances, partnerships and formalised networks with each other and with nongovernmental actors. At the operational level, coordinating devices to manage individual cases have been established. In the Law on Patient Rights (2001), the Norwegian government has guaranteed the right to individual care plans (ICPs) for patients with extensive and long-term needs, thereby institutionalising coordination on the operational level (Hanssen et al. 2018, p. 72). This initiative recalls similar efforts at service coordination in other nations, such as coordinated individual plans in Sweden and individualised support plans for people with intellectual disabilities in several English-speaking countries, Belgium and the Netherlands (Herps, Buntinx, Schalock, van Breukelen \& Curfs, 2016). More generally, the ICP resembles coordination devices for services for other social groups with extensive needs, such as municipal action plans drawn up for homeless persons in Denmark (Benjaminsen, 2017).

ICPs should ensure the integration of services in cases involving several care providers and attune professionals to users' needs and perspectives (Normann, Sandvin \& Thommesen, 2004). ICPs map patients' needs and resources, set their priorities and goals, assess possible actions and measures, designate specific contact persons and clarify responsibility for the provision of different services. Acknowledging that '[a]fter all, the user is not divided into sectors' (Ministry of Health, 1998; our translation; section 3.2.3, para. 11), the device is considered to be instrumental in strengthening critical collaboration within and across care, health and welfare services. Importantly, ICPs are meant to increase users' control over their own cases. 
The law states that ICPs do not guarantee access to more services but ensure their coordination. In this sense, it constitutes a procedural rather than a material right (cf. Hatland 2011). This right is further recognised in several related laws regulating the cross-sectoral fields of health, welfare and employment, particularly the 2006 Law on Work and Welfare Administration and the 2009 Law on Social Services. This broad juridification demonstrates the importance of this device to national policymakers (Grue \& Næss, 2012, p. 25). However, the provision of ICPs has been limited (Kjellevold, 2014). A 2011 study estimated that as much as six times more ICPs should have been issued (Bjerkan, Richter, Grimsmo, Hellesø \& Brender, 2011).

Focusing on the case of patients with traumatic brain injury, this study explored experiences of ICPs among staff in municipal coordinating units tasked with organising rehabilitation and staff working with rehabilitation patients in local labour and welfare services. Patients with traumatic brain injury generally face challenges in functioning and social and vocational participation, creating demand for a diverse set of closely coordinated services that ICPs can facilitate (Andelic et al., 2009). This study examined the processes underlying the limited use of ICPS in a cross-sectoral context. Few studies have considered such collaborative coordination devices from a cross-sectoral perspective, and there is a need to explore the mechanisms impeding their implementation (Bjerkan et al., 2011; Holum, 2012).

Adopting the approach of critical realism, we aimed to assess such mechanisms beyond the immediate empirical level. This approach suggests distinguishing between the empirical domain (what we experience and observe), the actual domain (what is happening) and the 'real' domain (the mechanisms behind what is happening) (Danermark, Ekström, Jakobsen \& Karlsson, 2002). Critical realism is intended to understand the causal powers of different material and immaterial entities. It argues that such powers may exist even if unexercised, and further, that they may be exercised but not actualised, i.e. producing an effect, due to other countervailing powers (O'Mahoney \& Vincent, 2014). This approach is pertinent as coordination ultimately is an exercise of power (Weber, 1971) that concerns not only the visible interactions among institutional actors but also their invisible mutual adjustments responding to or mutually anticipating choices and actions (Vabo, 2010, p. 345). Critical realism lends itself to the study of absence (Bhaskar 2014), in this case, the absence of individual care plans. 
We used empirical data from a vignette study involving focus groups with staff in municipal coordinating units and labour and welfare services providing vocational rehabilitation. The former had primary importance as these units take decisions regarding ICPs. Labour and welfare services typically enter at a later stage in the course of vocational rehabilitation. The vignette outlined the fictitious case of a patient with traumatic brain injury. To grasp the subject in more depth, we applied abduction and retroduction strategies. Through these modes of inference, we recontextualised the case within the larger understanding of service allocation in a universal welfare state and discussed the conditions behind our empirical observations in the field.

\section{Background}

The production and allocation of social services has been neglected in the general welfare state research, in which different systems of welfare have been appraised mainly through a focus on benefits (levels, duration and coverage) (Jensen, 2011; Martinelli, Anttonen \& Mätzke, 2017). Two partly inter-connected distinctions have arisen in the discussion on the principles of allocating welfare provisions, whether benefits or services: universal and targeted provision and centrally and locally organised systems. Regarding the former distinction, comparative welfare scholars in the tradition from Titmuss have proposed that the Nordic welfare states approximate the universal ideal type (Titmuss 1974; Esping-Andersen, 1990). In contrast to targeted welfare states that concentrate efforts on specially selected groups, the Nordic countries are characterized by an approach that accommodates broad groups on the basis of citizenship. Once an exclusively scientific concept, the notion of the Nordic welfare states as universal has become integral to these states' self-conceptions (Øverbye, 2018). Even amid rising demand for services, national authorities are increasingly embracing this idea (Vike, 2018, p. 139). Indeed, the notion of 'service universalism' is often applied to characterize Nordic citizens' access to health and welfare services irrespective of gender, age, social class and place of residence if they present a given need. However, to determine if the notion is valid, one should consider the actual service provision (Vabø \& Szebehely, 2012, p. 122).

Regarding the distinction between centrally and locally organised systems, the Nordic countries have been characterised as local autonomy centrally framed systems; while municipalities have a strong role in designing and delivering services, the state sets certain standards and ensures significant redistribution across territories (Kazepov, 2010). This description fits the Norwegian field of 
rehabilitation with services provided locally under terms stipulated at the central level (Breimo, 2015, p. 14). While adhering to the principles of universalism, most welfare services are produced and delivered by relatively autonomous local authorities (Vabo, 2014). Norway has a long tradition of local autonomy, significantly strengthened by the introduction of block grant financing in 1986 (conferring municipalities with stronger financial control) and consolidated by the 1992 Law of Municipalities (conferring municipalities with stronger organizational control) (Hanssen et al., 2018). The strong institution of ICPs as a right can be considered an attempt by the state to maintain universalist principles in the face of autonomous local authorities (Vabo, 2014, p. 166). Indeed, demonstrating the schism between universalism and local autonomy, local authorities long have openly objected to the state's expansion of their citizens' statuary rights to services (Hatland, 2011). We, therefore, can conceive of the state and the municipalities as entities with countervailing causal powers.

Amid this negotiation of responsibilities, the county governor, the state's representative in local governance, oversees the implementation of local coordinating units. Regional audit reports (e.g. County Governor of SørTrøndelag, 2013; County Governor of Buskerud, n.d.) have suggested that some municipalities have not satisfactorily established coordinating units, which are often not adequately visible to users and collaborating partners and sometimes lack staff training systems. Regarding the lack of visibility, it should be noted that although the term unit invokes the image of a physical entity with an office address and position in an organisational chart, municipalities are free to set them up as they wish, including as part of existing structures. In practice, the coordinating units may operate as more virtual constructions (Deloitte, n.d.).

\section{Method and Methodology}

This study considered the institutions set up to implement the goal set by national policy-makers to better coordinate services for users with complex needs. The primary entities considered were ICPs, the coordinating units charged with delivering them and their relationships to other entities such as labour and welfare services, general practitioners (GP) and the larger welfare state. We based the study on focus groups with professionals in municipal rehabilitation services and local labour and welfare services in south-eastern Norway. Focus group interviews, generally with three or four participants, were 
conducted in eight municipalities in 2015 and $2016 .{ }^{1}$ Choosing to conduct focus groups instead of individual interviews served the interest in understanding the practices of the selected institutions (i.e. exploring the properties and relationships of the entities) rather than the practices of individual professionals. This study was part of a larger project exploring critical aspects of rehabilitation and the organisation of services. The project involved a user panel of representatives from user organisations who had personal experiences with traumatic brain injuries as patients or patients' next of kin. We consulted the panel before the field study (during preparation of the vignette and the interview guide) and during the analysis of the preliminary results, as elaborated in the following sections.

\section{Data Collection}

Relevant municipalities were identified based on information provided by specialised hospitals showing who had residents recently diagnosed with traumatic brain injury. Possibly reflecting deficient implementation of the coordinating units (see the preceding considerations) in several municipalities, it proved difficult to identify these units in the local administrative structure and to find contact persons, let alone schedule interview appointments. We, therefore, could assume that municipalities where patients struggle to obtain ICPS due to the lack of well-functioning coordinating units were underrepresented in the data. The coordinating unit interviews arranged included both professional caseworkers and therapists working with rehabilitation patients (i.e. physiotherapists, occupational therapists and nurses). Different professional groups (i.e. social workers and caseworkers with backgrounds in other social and administrative sciences) participated in the interviews with labour and welfare services staff (see Appendix tables 1 and 2).

As a point of departure for the interview, we used a vignette describing a hypothetical scenario involving a patient with traumatic brain injury. Using vignettes is an appropriate alternative in situations where it is difficult to get data on decision- and judgment-making (Morrison, Stettler \& Anderson, 2004). To

\footnotetext{
${ }^{1}$ Due to last-minute cancelations, two focus group interviews with labour and welfare services staff had only two participants. Although this sample size was too small to constitute a focus group, we judged the information generated to have value and retained it in the data.
} 
improve validity, the vignette, following Wilks (2004), was developed in close collaboration with rehabilitation practitioners, as well as the project's user panel. The vignette detailed a 34-year-old carpenter's health condition (traumatic brain injury, cerebral haemorrhage and temporary paralysis in the left extremities), treatment and social situation (married, two children). His GP declared him $100 \%$ disabled for the time being. The vignette patient reflected a realistic case in terms of socio-demographics and cause of trauma based on epidemiological studies (Brazinova et al., 2016) and was clearly in the target group envisaged in the law introducing ICPs (Hagen \& Johnsen, 2013, p. 40n).

The interview guide explored how the participants likely would handle the case. What concrete actions would they do? What information and documentation would they request from other actors and agencies? What mapping and evaluations would they undertake and commission? How would they judge the case patient's potential for recovery and labour market reintegration? We used several probing questions to follow up on responses.

\section{Analytical Approach}

Inspired by the philosophy of science position of critical realism, we adopted the analytical strategies of abduction and retroduction. Unlike induction, abduction entails taking a point of departure in data derived from a theory-informed research agenda, but unlike deduction, the analysis is not tied to hypotheses formulated before data collection. Abduction, therefore, is a 'creative inferential process' aimed at producing new hypotheses from unanticipated empirical observations (Timmermans \& Tavory, 2012, p. 167). Retroduction offers a framework for analysing such observations in a manner sensitive to the wider context of the phenomenon under study (Bunt, 2016). Retroduction entails recontextualisation, a mode of inference that assesses the properties of a certain phenomenon at a higher level of abstraction (Danermark, et al., 2002).

Thematic analysis was conducted to construct common categories from the empirical data in the study participants' accounts of using ICPs and related practices for handling cases. We condensed the initial codes into analytical categories describing the functions and the usage of ICPs in practice. In critical realism terminology, these procedures of making categories from observations represent an interpretive move from the empirical (what we observe) to the actual (a reading of the state of affairs) domain. This move involves 'a process of inference from lay (first-order) to sociological (or second-order) accounts of the social world' (Scambler, 2002, p. 11). 
In making these inferences involving critical appraisal of first-order accounts (how the professionals described their practice of working with rehabilitation patients and using/not using the ICP), we also drew on secondary literature (other studies from the field). Moreover, we leaned on discussions with the user panel, whose comments on the data guided our analysis. Going beyond the fixed corpus of interview data in such a manner, is suggested by Smith and Elger (2014, p. 120), in their account of the critical realist approach to the interview method. The approach is especially warranted when the primary data are derived from vignette-based interviews as this method carries the risk of not obtaining an accurate account of actual practice (Wilks, 2004, p. 82).

The next step of going from the actual to the real domain necessitates an interpretive discussion of these categories in light of relevant concepts and theories. Critical realism views the social world as an open system, stratified into layers with emergent properties (O'Mahoney \& Vincent, 2014). Adopting the notion of open systems requires acknowledging that we face a dynamic social world in which institutional actors constantly make adjustments (Danermark et al., 2002). Understanding professional practice, therefore, requires considering the wider perspectives of the organisational and social contexts. Given that macro factors are 'interlocked with social activities' (Layder, cited in Bunt, 2016, p. 5), the interpretive discussion becomes a process of teasing out these macro-level structures from micro-level observations. ${ }^{2}$ Sayer (1992) suggests guiding this process by posing simple questions on the nature and preconditions of the phenomenon being studied. In this study, we asked: What do ICPs presuppose? What are their causal properties? How are they supported or suppressed within the larger social context?

\section{Empirical Analysis}

\section{The Individual Care Plan as a Resource in the Rehabilitation Process}

The professionals participating in the focus group interviews generally approached the vignette case from a holistic perspective. They discussed

\footnotetext{
${ }^{2}$ The critical realism analysis presented in this article is only partial. A full analysis would also include analytical moments of elimination and identification involving critical assessment of the plausible mechanisms suggested by the process of retroduction. Such assessment might demand use of more refined perceptual instruments (Bhaskar, Danermark \& Price, 2018).
} 
aspects such as the person's bodily impairments, physiotherapy, coping strategies, reduced capacity, need for income support and mental health treatment, support for his wife and family and potential for a gradual return to work. The participants all pointed to several services in addition to their own from which the patient and his family could benefit. They thus generally demonstrated a caring, supportive approach and considered the user's problems and needs from many different angles.

In the interviews with coordinating unit staff, ICPs stood out as significant resources for those users who received them. Among other factors, the professionals considered ICPs to be a resource supporting a holistic approach towards users' situations:

What is so brilliant about the coordinating meetings and the individual care plan is that you get insight into the user's situation in its entirety. Because many general practitioners participate in the coordinating meetings, some may not be able to participate [in the meetings], but still they contribute by providing information. (CoU4)

This apparent characteristic of ICPS should be emphasised as previous research has suggested that the actors involved in rehabilitation think that the lack of a holistic approach causes setbacks in the rehabilitation process (Harsløf, Søbjerg Nielsen \& Feiring, 2017).

Importantly, in the eyes of the professionals we interviewed, ICPs seemed to be instrumental in bringing users' GP to collaborate with the other service providers. Consequently, the GPs attended meetings or were at least kept in the critical circulation of case information. Sometimes GPs even took on the role of coordinator. Previous research has indicated that other actors involved in the rehabilitation process have difficulty obtaining constructive collaboration with GPs (Håvold, Harsløf \& Andreassen, 2018). The involvement of GPs facilitated by the ICP framework, therefore, might make critical differences in approaches to cases and provide additional support for the rehabilitation process.

The professionals praised ICPs for providing a setting that stimulated decisionmaking:

It works. We never leave a meeting without making decisions. (CoU4)

However, other research participants emphasised that ICPs themselves were no guarantee of coordinated action:

An individual care plan is great for those who need it when it is used. However, there are many such plans just lying in the drawer, and then they are not worth the paper they were written on. (CoU5) 
An important relevant point emphasised by one interviewee (CoU4) was that what ultimately mattered was not the plan but the services.

When asked about the vignette patient, most coordinating unit professionals said that it would be appropriate to establish an ICP in this case:

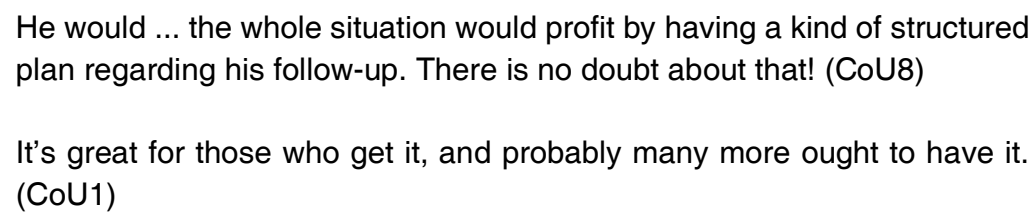

Labour and welfare services staff may occasionally be invited into the ICP process to coordinate decisions with implications for users' economic maintenance and participation in return-to-work measures. From the perspective of the staff members working with this group of users, ICPs also appeared to constitute a salient resource for users. They stressed the need for a designated person to 'pull the strings a little' (LWS8) to set in motion, follow up and coordinate various services. Referring to the patient group (patients with traumatic brain injury) represented in the vignette, a focus group participant noted:

This group has a very strong need for a coordinator who can help them find their way back into mainstream society where they are to go after rehabilitation. (LWS7)

While acknowledging the importance of collaborating with labour and welfare services in the case at hand, the professionals with the coordinating units critiqued communication with this agency as arduous:

They are not easy to get hold of. ... I've send reports to the caseworker, but I don't get any response on whether she got them at all and whether she has looked at them. I don't get anything back. (CoU2)

They [labour and welfare services] find it difficult to attend meetings ... When they are here, they sort of ask us to focus on the economic issues ... Then I think we're losing the inter-professional element. ... Then they are not involved in the case in its entirety. (CoU3)

In one municipality, labour and welfare services were formally integrated into the overall coordinating efforts and represented in the coordinating unit. The participants attributed the coordinating unit's success in making concrete agreements on sharing responsibilities for individual cases to this arrangement. 


\section{Limited Usage in Some Municipalities}

Although the professionals saw ICPs as significant resources for users, several focus group participants acknowledged that they too seldom used ICPs.

To be honest, there are not many in this patient group that have an individual care plan here. ... So we have a big job ahead of us, but I reckon that as of today, this guy [from the vignette] wouldn't have gotten an individual care plan. (CoU8)

Remarkably, some focus group participants reported that they used ICPs more immediately after their introduction in the early 2000 s.

Participant A: It was used much more before, I think, ... when it was new, and we were instructed by the law to use it, I would almost say.

Participant B: Well, we are still instructed by the law now.

Participant A: Yes, I know that, but ... at least among the users I've got, we used it much more before. (CoU3)

This exchange shows that while the professionals were aware that patients' right to ICPs had been instituted, they in practice had a great deal of discretion in deciding whether to provide ICPs. Arguably, the exchange gives insight into the dynamics in open systems, in other words, how the institutional actors adapted, from the response to the initial stimuli of the law's introduction ('when it was new') to apparently longer-term resignation, drifting towards the previous equilibrium.

Labour and welfare service staff working on rehabilitation cases seldom mentioned the topic of ICPs or even the municipal coordinating units in the focus group discussions. We can tentatively attribute this absence to deficient implementation of visible coordinating units and the ICP instrument. Indeed, these staff members evinced a more general concern about the common lack of coordinating arrangements for the type of patient featured in the vignette:

This is where things start becoming a little difficult. In a way, it is difficult to see who is to be the coordinator at any given point in time. Soon there are many who are pointing at each other because it is not very clear who is to sit in the driver's seat. (LWS7)

The observation that designating a coordinator often ended with different actors 'pointing at each other' also surfaced in a study on social workers working in specialised rehabilitation hospitals (Harsløf et al., 2017). The reason might be that the coordinator carries large responsibilities being accountable for the various service providers' efforts, or lack thereof, to implement the plan (Breimo, Normann, Sandvin \& Thommesen, 2015). 
In addition to the problem of designating coordinators, the interviewees suggested several other reasons why ICPs were seldom applied. The professionals argued that drawing up these plans was cumbersome, and few employees possessed the skills and competencies to do so:

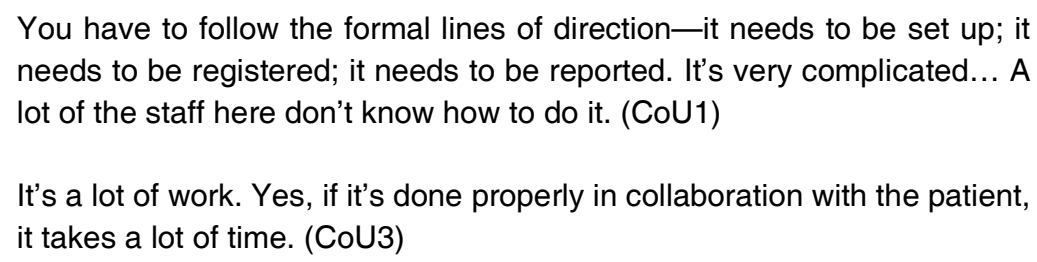

The interview material did not contain further information on the kinds of skills needed to implement ICPs, but the literature review and discussions with the user panel suggested that information and communications technology skills and knowledge about privacy laws were important, among others (cf. Hollingen, 2008, pp. 29-31; Kjellevold, 2002, p. 61).

Several interviewees stated that they did not take the initiative to draw up plans unless users actively requested them:

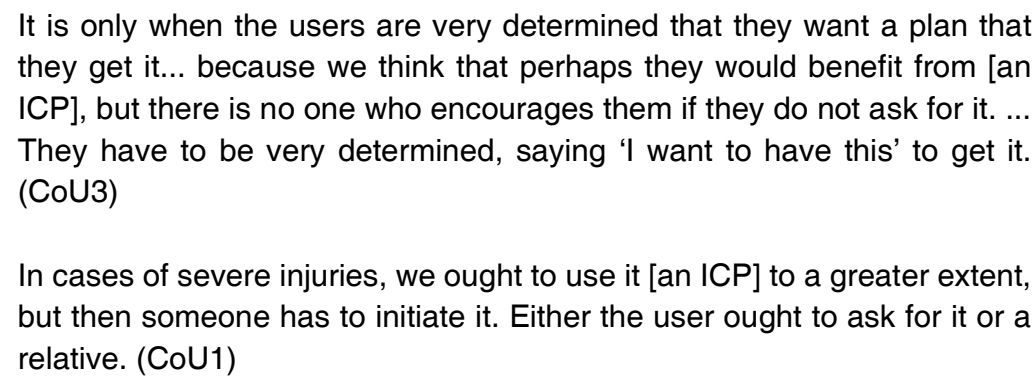

Some municipalities seemed to have a practice requiring users to come forward and express a desire for ICPs. The material was not in full unison on this point. In one case (CoU6), a research participant declared that contrary to this practice, she did much to actively persuade patients' relatives to accept ICPs. However, our observation that the staff in some municipalities were reluctant to initiate ICPs without explicit requests from users or their relatives has been corroborated by experiences reported elsewhere (Osgjelten \& Wirak, 2004, p. 48).

\section{A Recontextualisation}

\section{The Individual Care Plan as a Boundary Object}

The critical realism approach discourages reifying the object studied. Hence, whereas an empiricist would ask whether an ICP has been established (treating 
it as a discrete event), critical realism encourages us to emphasise the perspectives of the research participants that argue that what ultimately matter are the services delivered through the plan. A plan just 'lying in the drawer' has no real value, while other local practices can facilitate coordination and user involvement even in the absence of a formal plan. Critical realism also distances itself from post-structural positions solely focused on how the semiotics of planning devices construe users and their needs. Leaning on the participants' testimonies, therefore, it should be acknowledged that ICPs, when implemented, constitute a critical resource in users' rehabilitation. The research participants credited ICPs for improving the conditions for decision-making, bringing holistic perspectives to bear on cases and facilitating collaboration among significant actors and organisations.

Theoretically, such causal properties can be understood with reference to the notion of boundary objects (Star, 1988; Star \& Griesemer, 1989). Boundary objects are repositories of information that sustain common representations among actors with different professional backgrounds and institutional affiliations. These constructs are supposed to be sufficiently robust to be valid across actors while sufficiently adaptable to be useful to all the actors. ICPS approximate boundary objects as they assemble and structure comprehensive information about users' aims and needs, the services and their potential and make this information available to all the participating actors.

Returning to the viewpoint that what really matters is the services (rather than the plan document itself), we can think of the ICP-induced activities of mapping needs and measures and the emphasis on user involvement as likely facilitating better access to services; it may be easier to substantiate a claim for a service, when it is prescribed in an ICP (see Breimo et al., 2015, p. 45). ICPs' nature as boundary objects might further reinforce this mechanism. Rooted in a plan with institutional recognition across professions and sectors, a need articulated by one institutional actor can be more easily appreciated by another. This mechanism is an important causal property as it transforms the ICP from a procedural right into a vehicle for realising material rights to services.

\section{A Case of Self-Targeting?}

Despite the general praise, it seems that in several cases, persons with complex needs, as in the vignette case, would be unlikely to receive ICPs. In some municipalities, ICPs are provided based on de-facto self-targeting: users have to request them and demonstrate strong motivation. Patients with traumatic 
brain injury, however, likely have limited capacity for such self-direction due to their physical and mental state and the stressful social situation they find themselves in (Finset, Dyrnes, Krogstad \& Berstad, 1995).

To understand the observed reluctance to establish ICPs, we may first look at what is at stake for local service providers. According to Leutz (1999), most efforts to integrate health and social services initially entail additional costs. Regarding ICPs, we can think of the costs of the extra administrative work involved, efforts to bring service providers together and, as discussed, increased services that users might ultimately be able to access. The interviewees did not specifically refer to funding issues, but we note that they did mention a lack of suitably qualified personnel and the strain on municipal service providers working with ICPs.

Moreover, ensuring integration for some, Leutz (1999) notes, necessarily involves fragmentation for others. Even if we conceive of ICPS as relatively adaptable boundary objects, by contributing to the integration of services, the work situation of the service personnel involved is likely to become more fragmented. Involvement in implementing ICPs, particularly as coordinators, sometimes makes personnel operate at the margins of their professional expertise. They must expand their knowledge and accommodate users' specific situations (in this regard, see Danermark, 2004, p. 31). Moreover, the emphasis on strengthening user involvement through ICPs may itself be experienced as a threat to the professionals' power (Kortteisto, 2017).

If we conceive of the practice of issuing ICPs as, in some municipalities, approximating de-facto self-targeting, we may ask what the conditions constituting this practice are. Whereas conventional targeting identifies the neediest cases, self-targeting adds the twist that the claimant needs to act in a required manner in order to enter the target group. Hence, self-targeting is 'designed in such a way that only members of the target group find it worthwhile to participate ... the incentives to participate are themselves the screen' (Haddad \& Kanbur, 1992, p. 374). Undertaking the required activities may reflect needs but also the degree of motivation and capacity to make sufficient usage of services. In other words, self-targeting may be a means to ration ICPs and the services to which ICPs may ease access, favouring those with the potential to actively participate in the plan to self-reliance.

In sum, ICPs appear to have critical causal properties important to rehabilitate patients but consequently put strain on service providers and local social 
services, which may explain the reluctance to implement ICPs and the practice of de-facto self-targeting identified in some municipalities.

\section{Conclusion}

Many countries have introduced devices intended to coordinate services for groups with complex and long-lasting needs. Understanding how such devices are implemented and function is important to grasp the mechanisms through which social services are allocated. Norwegian national policymakers have made ICPs an important initiative to foster cross-sectoral coordination and user involvement in complex patient cases. However, local application of ICPs has so far not reached the anticipated level. This study considers ICPs to be entities possessing causal properties within a system of interrelated institutions. We, therefore, identify mechanisms that may explain this underuse.

The service professionals regarded ICPs as instrumental in creating momentum in physical and vocational rehabilitation. They viewed ICPs as facilitating more holistic approaches to cases and settings conducive to concrete decisionmaking. They reported that ICPs attract and gain commitment from important actors, such as GPs, and enable better communication across sectors. To understand these causal properties of ICPs, we suggest considering them as boundary objects. As such, they potentially ease access to social services as claims articulated in plan documents are more easily recognised by actors in different sectors.

However, corroborating findings from previous research (Kjellevold, 2014; Bjerkan et al. 2011), the service professionals acknowledged that even a person in the prime target group, such as the vignette patient, might be unlikely to receive an ICP. It appears that in some municipalities, users-despite having limited capacity for self-direction-are expected to come forward themselves and demand ICPs, which the municipalities are reluctant to offer as a matter of course. We take such practices to indicate de-facto self-targeting; users, in a sense, are screened, and access is granted only to those capable of agitating for themselves. The empirical material suggests that establishing and operating ICPs requires time and certain competencies. Screening may ration such scarce resources and ensure that the selected recipients have both the need and the potential to benefit from comprehensive services.

While self-targeting can be explicitly adopted as a strategy to allocate scarce resources, we use the term metaphorically as part of a creative recontextualisation (Jacobsen, 2015) of our observations from the field. Further studies 
are needed to assess whether the notion of self-targeting is suitability for understanding the local allocation of rehabilitation services, preferably by investigating users' experiences. Further studies should also investigate whether practices accommodated by this concept are performed in other userwelfare state interfaces. ${ }^{3}$ In addition, researchers could consider how the insufficient implementation of ICPs is justified in wider municipal contexts. For instance, how does local social services management articulate expectations as regards the level of ICPs being drawn up?

A potential macro-level factor lurking in the practice of coordinating services for rehabilitation patients is the schism between universalist principles and strong local autonomy in the Norwegian welfare state. The universal welfare state kind of reckons without its host, establishing ICPs as a universal right in numerous healthcare, labour and welfare regulations while leaving it up to municipalities and ultimately service professionals to implement this measure, and carry the extra costs. However, considered at a more abstract level, we may be observing a self-maintaining (autopoietic) system that seems able to uphold the perception of a universal welfare state precisely by resorting to mechanisms of de-facto self-targeting in local service delivery.

Critical realism guides us to consider the nature of this service-planning device, the relationships among the service providers that constitute it and thus what is at stake in decisions involving it. The approach allows us to acknowledge that simply calling for new measures to ensure that all those entitled to ICPs receive them does not necessarily accommodate users' needs without a corresponding increase in the availability of staff, including GPs and labour and welfare service professionals to follow them through, let alone an increase in available social services. The open system approach entailed by critical realism makes sense of the observed practices, particularly how institutional actors adapt to systemic changes and gradually game the process (as exemplified in that coordinating

${ }^{3}$ For example, a recent Norwegian study gives reasons to ask whether self-targeting is practised in the allocation of aftercare services to young people ageing out of foster care (Valset, 2018). Unlike for ICPs, receiving aftercare is not a right, but child welfare services (CWS) has been instructed to determine the needs in all individual cases. Analysing administrative data, Valset finds a curvilinear relationship between young adults' resources (reflected in school performance, such as grades) and likelihood of receiving aftercare. She suggests that the remaining careleavers may 'lack the knowledge and motivation for seeking further support from the CWS at this age and then "sign out" of the system prematurely' (Valset, 2018, p. 13). 
unit that initially used ICPs frequently, 'when it was new', but later less so, despite the law being the same).

However, even if we interpret self-targeting as a strategy adopted by single caseworkers, rather than an individualistic coping mechanism, the critical realism approach leads us to consider it to be the working of an institutional agent (the coordinating unit) within a larger social context (the municipal and ultimately national frameworks). In view of critical realism's concern for absence (Bhaskar 2014), the apparent lack of visible, well-functioning coordination units in some municipalities should be emphasized. Hence, this lack may in itself contribute to the ICPs' underuse; targeting oneself for the ICP service becomes even more challenging when it is difficult to locate the service provider. Moreover, in more traditional analytical approaches, the simultaneous existence of municipalities that readily offer ICPs and municipalities that exhibit selftargeting practices would be conceived of as phenomena cancelling out each other. However, critical realism guides us to infer that self-targeting exists as a latent mechanism even if it is not always exercised.

As to the critical element in critical realism, this study gives reason to raise questions about the Nordic welfare states' self-conception regarding service universalism. When universal welfare rights proclaimed nationally are not sustained by sufficient local resources, it might result in de-facto self-targeting arrangements that mainly benefit users with strong self-direction or relatives who can act on their behalf. In Norway, through measures introduced under headings such as 'collaboration reform', ' 'coordination units' and 'individual care plans', national policymakers have articulated a rather harmonious perspective on social services production and allocation, implying that recurring problems are solvable through better collaboration, coordination and planning. What is downplayed is the perspective that services are produced, delivered and consumed by actors who have something at stake (May \& Winter, 2007) and are dependent on inherently scarce resources, leaving it to local actors and ultimately service professionals, in their capacity as rationing agents, to cope with these societal contradictions (Houston, 2001).

\footnotetext{
${ }^{4}$ In English, this reform is usually called the coordination reform. However, the term collaboration is closer to its Norwegian name, samhandlingsreformen (Hanssen et al., 2018, p. 175).
} 


\section{Acknowledgements}

This research was part of the project Transitions in Rehabilitation: Biographical Reconstruction, Experiential Knowledge and Professional Expertise, financed by a grant from the Research Council of Norway (grant no. 229082). We thank project leader Tone Alm Andreassen and the team for their valuable contributions. We also thank May-Britt Solem for comments and support. Finally, we thank the three reviewers and Nordic Journal for Social Research's editorial team for their extensive and valuable comments.

\section{Appendix}

Table 1: Overview of the focus group interviews with coordinating unit staff

\begin{tabular}{|c|c|c|c|c|c|c|}
\hline & & \multicolumn{5}{|c|}{ Professional background of the study participants } \\
\hline & & $\begin{array}{l}\text { Registred } \\
\text { nurse }\end{array}$ & $\begin{array}{l}\text { Physical } \\
\text { therapist }\end{array}$ & $\begin{array}{l}\text { Occupa- } \\
\text { tional } \\
\text { therapist }\end{array}$ & $\begin{array}{l}\text { Auxiliary } \\
\text { nurse }\end{array}$ & $\begin{array}{l}\text { Social worker, cultural } \\
\text { worker or social } \\
\text { educator }\end{array}$ \\
\hline COU1 & $\begin{array}{l}\text { City district, } 24,000 \\
\text { inhabitants }\end{array}$ & 1 & 1 & 1 & - & - \\
\hline cou2 & $\begin{array}{l}\text { City, } 65,000 \\
\text { inhabitants }\end{array}$ & 2 & 1 & 2 & 1 & - \\
\hline cou3 & $\begin{array}{l}\text { Rural municipality, } \\
10,000 \text { inhabitants }\end{array}$ & 1 & 2 & 1 & - & 1 \\
\hline COU4 & $\begin{array}{l}\text { City in a rural district, } \\
25,000 \text { inhabitants }\end{array}$ & 2 & 1 & - & - & 1 \\
\hline COU5 & $\begin{array}{l}\text { City in a rural district, } \\
30,000 \text { inhabitants }\end{array}$ & 1 & 1 & 1 & - & 2 \\
\hline COU6 & $\begin{array}{l}\text { City, } 45,000 \\
\text { inhabitants }\end{array}$ & - & 1 & 1 & - & 1 \\
\hline COU7 & $\begin{array}{l}\text { Rural municipality, } \\
52,00 \text { inhabitants }\end{array}$ & 2 & - & - & 1 & - \\
\hline cou8 & $\begin{array}{l}\text { City district, } 27,000 \\
\text { inhabitants }\end{array}$ & 2 & 2 & 1 & - & - \\
\hline
\end{tabular}

Table 2: Overview of focus group interviews with local work and welfare services staff

\begin{tabular}{|c|c|c|c|c|c|c|}
\hline \multirow[b]{3}{*}{ LWS1 } & \multirow[b]{3}{*}{$\begin{array}{l}\text { City district, } 48,000 \\
\text { inhabitants }\end{array}$} & \multicolumn{5}{|c|}{ Educational background of the interview participants } \\
\hline & & $\begin{array}{l}\text { Master's in } \\
\text { social } \\
\text { sciences* }\end{array}$ & $\begin{array}{l}\text { Social } \\
\text { work/social } \\
\text { education }\end{array}$ & $\begin{array}{l}\text { Health } \\
\text { Sciences }\end{array}$ & Law & Other \\
\hline & & 2 & 1 & - & - & - \\
\hline LWS2 & $\begin{array}{l}\text { Suburban municipality, } \\
60,000 \text { inhabitants }\end{array}$ & 1 & 1 & - & 1 & 2 \\
\hline LWS3 & $\begin{array}{l}\text { Rural municipality, } 10,000 \\
\text { inhabitants }\end{array}$ & - & 3 & - & - & 1 \\
\hline LWS4 & City, 80,000 inhabitants & 1 & 2 & 1 & - & 1 \\
\hline LWS5 & $\begin{array}{l}\text { Rural municipality, } 13,000 \\
\text { inhabitants }\end{array}$ & - & - & - & 2 & - \\
\hline LWS6 & $\begin{array}{l}\text { City in a rural district, } \\
30,000 \text { inhabitants }\end{array}$ & 1 & - & 1 & - & 1 \\
\hline LWS7 & City, 50,000 inhabitants & 1 & 1 & - & - & 1 \\
\hline LWS8 & City district, 45,000 & - & - & 1 & - & 1 \\
\hline
\end{tabular}


* Political science, sociology or criminology

NJSR - Nordic Journal of Social Research 


\section{References}

Andelic, N., Hammergren, N., Bautz-Holter, E., Bautz-Holter, E., Sveen, U., Brunborg, C., \& Røe, C. (2009). Functional outcome and health-related quality of life 10 years after moderate-to-severe traumatic brain injury. Acta Neurologica Scandinavica, 120, 16-23. https://doi.org/10.1111/j.1600-0404.2008.01116.x

Benjaminsen, L. (2017). Hjemløshed i Danmark 2017: national kortlægning, report 09:25 [Homelessness in Denmark 2017]. Copenhagen, Denmark: VIVE.

Bhaskar, R. (2014). Foreword. In P. K. Edwards, J. O'Mahoney \& S. Vincent (Eds.), Studying organizations using critical realism: a practical guide (pp. v-xv). Oxford, UK: Oxford University Press.

Bhaskar, R., Danermark, B., \& Price, L. (2018). Interdisciplinarity and wellbeing. A critical realist general theory of interdisciplinarity. London, UK: Routledge. https://doi.org/10.4324/9781315177298

Bjerkan, J., Richter, M., Grimsmo, A, Hellesø, R., \& Brender, J. (2011). Integrated care in Norway: the state of affairs years after regulation by law. International Journal of Integrated Care, 11. https://doi.org/10.5334/ijic.530

Brazinova, A., Rehorcikova, V., Taylor, M. S., Buckova, V., Majdan, M., Psota, M. Peeters, W., Feigin, V., Theadom, A., Holkovic, L. \& Synnot, A. (2016). Epidemiology of traumatic brain injury in Europe: a living systematic review. Journal of Neurotrauma. 33:1-30. https://doi.org/10.1089/neu.2015.4126

Breimo, J. P. (2015). Captured by care: an institutional ethnography on the work of being in a rehabilitation process in Norway. Journal of Sociology \& Social Welfare, 42(2).

Breimo, J. P., Normann, T., Sandvin, J. T., \& Thommesen, H. (2015). Individuell plan: samspill og unoter [The individual care plan]. Oslo, Norway: Gyldendal Akademisk.

Bunt, S. (2016). Critical realism and grounded theory: analysing the adoption outcomes for disabled children using the retroduction framework. Qualitative Social Work, 17(2): 176-194. https://doi.org/10.1177/1473325016664572

County Governor of Sør-Trøndelag. (2013). Kartlegging av status for arbeidet med koordinerende enhet for habilitering og rehabilitering (KE), herunder overordnet ansvar for individuell plan (IP) og koordinator [Mapping the status for the work with the coordinating unit for habilitation and rehabilitation]. Retrieved from http://www.fylkesmannen.no/Documents/Dokument\%20FMST/Helse\%20og\%20 omsorg/Individuell\%20plan/2013\%20Fylkesmannens\%20kartlegging\%20av\%20 status $\% 20$ KE\%20og\%20IP/Kartlegging\%20av\%20status\%20for\%20arbeidet $\% 2$ Omed\%20koordinerende\%20enhet\%20individuell\%20plan\%20og\%20koordinato r\%20-\%20Rapport\%20april\%202013.pdf

County Governor of Buskerud. (n.d.). Individuell plan, koordinator og koordinerende enhet [Individual care plan, coordinator and coordinating unit]. Retrieved from https://www.fylkesmannen.no/globalassets/fm.../ip-og-koordinerendeenhet.pptx.

Danermark, B. (2004). Samverkan-en fråga om makt [Cooperation-a question of power]. Örebro, Sweden: LäroMedia.

Danermark, B., Ekström, M., Jakobsen, L., \& Karlsson, J. C. (2002). Explaining society: critical realism in the social sciences. London, UK: Routledge.

Deloitte. (n.d.). FoU-prosjekt 144007: rehabilitering: konsekvenser for kommunene av den stille reformen. [Rehabilitation: consequences for the municipalities of the the 
quit reform] Retrieved from http://www.ks.no/contentassets/c0c501426c784c91ab253c9feaf7ac36/rapport.p df.

Esping-Andersen, G. (1990). The three worlds of welfare capitalism. Cambridge, UK: Polity.

Finset, A., Dyrnes, S., Krogstad, J. M., \& Berstad, J. (1995). Self-reported social networks and interpersonal support 2 years after severe traumatic brain injury Brain Injury, 9, 141-150. https://doi.org/10.3109/02699059509008187

Grue, L. P., \& Næss, A. (2012). Habilitering som koordinerende tiltak: erfaringer fra tre brukergrupper. [Habilitation as a coordinating measure: experiences from three user groups]. NOVA rapport, Oslo, Norway. https://doi.org/10.7577/nova/rapporter/2012/4

Haddad, L., \& Kanbur, R. (1992). Intrahousehold inequality and the theory of targeting. European Economic Review, 36, 372-378. https://doi.org/10.1016/00142921(92)90093-C

Hagen, R., \& Johnsen, E. (2013). Styring gjennom samhandling [Governance through collaboration]. In A. Tjora \& L. Melby (Eds.), Samhandling for helse: Kunnskap, kommunikasjon og teknologi $i$ helsetjenesten. Pp. 31-53. Oslo, Norway: Gyldendal Akademisk.

Hanssen, G. S., Helgesen, M. K., \& Vabo, S. I. (2018). Politikk og demokrati: En innføring $i$ stats-og kommunalkunnskap [Politics and democracy], $4^{\text {th }}$ ed. Oslo, Norway: Gyldendal Akademisk.

Harsløf, I., Søbjerg Nielsen, U., \& Feiring, M. (2017). Danish and Norwegian hospital social workers' cross-institutional work amidst inter-sectoral restructuring of health and social welfare. European Journal of Social Work, 20(4). https://doi.org/10.1080/13691457.2016.1188783

Hatland, A. (2011). Rettsliggjøringen av velferdspolitikken [Juridification of welfare policies]. In A. Hatland (Ed.)., Veivalg i velferdspolitikken (pp. 153-172). Bergen, Norway: Fagbokforlaget.

Herps, M. A., Buntinx, W. H. E., Schalock, R. L., van Breukelen, G. J., \& Curfs, L. M. (2016). Individual support plans of people with intellectual disabilities in residential services: content analysis of goals and resources in relation to client characteristics. Journal of Intellectual Disability Research, 60, 254-262. https://doi.org/10.1111/jir.12245

Hollingen, A. (2008). Brukererferinger med nettbasert individuell plan [User experiences with web-based ICP] (Unpublished master's thesis). Molde, Norway: Molde University College.

Holum, L. C. (2012). 'It is a good idea, but...' A qualitative study of implementation of 'individual plan' in Norwegian mental health care. International Journal of Integrated Care, 12. https://doi.org/10.5334/ijic.809

Houston, S. (2001). Beyond social constructionism: critical realism and social work. British Journal of Social Work, 31, 845-861. https://doi.org/10.1093/bjsw/31.6.845

Håvold, O. K, S., Harsløf, I., \& Andreassen, A. (2018). Externalizing an 'asset model' of activation: creative institutional work by frontline workers in the Norwegian labour and welfare service. Social Policy and Administration. 52(1): 178-196. https://doi.org/10.1111/spol.12305 
Jacobsen, M. H. (2015). Den metaforiske fantasi: kreativ rekontekstualisering og rekonstruktion i kvalitativ metode [The metaphorical imagination: creative recontextualisation and reconstruction in qualitative method]. In J. E. Møller, S. S. E. Bengtsen \& K. P. Munk (Eds.), Metodefetichisme: kvalitativ metode på afveje? [Methodological fetishism: qualitative methods astray?] (pp. 193-212). Århus, Denmark: Århus Universitetsforlag.

Jensen, C. (2011). The forgotten half: analysing the politics of welfare services. International Journal of Social Welfare, 20, 404-412. https://doi.org/10.1111/j.1468-2397.2010.00745.x

Kazepov, Y. (2010). Rescaling social policies towards multilevel governance in Europe. Surrey, UK: Ashgate.

Kjellevold, A. (2002). Retten til individuell plan og koordinator [The right to individual care plan and coordinator]. Bergen, Norway: Fagbokforlaget.

Kjellevold, A. (2014). Individuell plan i helse-og omsorgstjenesten-behov for endringer og ansvarliggjøring? [The individual care plan in the health care services]. Tidsskrift for erstatningsrett, forsikringsrett og velferdsrett, 11, 267-300.

Kortteisto, T., Laitila, L., \& Pitkanen, A. (2017). Attitudes of mental health professionals towards service user involvement. Scandinavian Journal of Caring Sciences. 32(2):681-689.

Law on patient rights (2001), LOV-2018-06-15-38. Retrieved from https://lovdata.no/dokument/NL/lov/1999-07-02-63.

Leutz, W. N. (1999). Five laws for integrating medical and social services: lessons from the United States and the United Kingdom. The Milbank Quarterly, 77, 77-110. https://doi.org/10.1111/1468-0009.00125

Martinelli, F., Anttonen, A., \& Mätzke, M. (Eds.). (2017). Social services disrupted: changes, challenges and policy implications for Europe in times of austerity. Cheltenham, UK: Edward Elgar. https://doi.org/10.4337/9781786432117

May, P. J., \& Winter, S. (2007). Collaborative service arrangements. Public Management Review, 9, 479-502. https://doi.org/10.1080/14719030701726473

Morrison, R. L., Stettler, K., \& Anderson, A. E. (2004). Using vignettes in cognitive research on establishment surveys. Journal of Official Statistics, 20(2), 319-340.

Normann, T., Sandvin, J. T., \& Thommesen, H. (2004). A holistic approach to rehabilitation. Oslo, Noway: Kommuneforlaget.

Ministry of Health. (1998). St.meld. nr. 21 (1998-99), Ansvar og meistring [Responsibility and coping]. Oslo, Norway: Author.

O'Mahoney, J., \& Vincent, S. (2014). Critical realism as an empirical project: a beginner's guide. In P. K. Edwards, J. O'Mahoney \& S. Vincent (Eds.), Studying organizations using critical realism: a practical guide (pp. 1-20). Oxford, UK: Oxford University Press. https://doi.org/10.1093/acprof:0so/9780199665525.003.0001

Osgjelten, R. T., \& Wirak, M. T. (2004). Foreldreerfaringer [Parental experiences]. In O. P. Askeheim, T. Andersen \& J. Eriksen (Eds.), Sosiale tjenester for familier som har barn med funksjonsnedsettelser (pp. 47-55). Oslo, Norway: Gyldendal Akademisk.

Renner, I., Saint, V., Neumann, A., Ukhova, D., Horstmann, S., Boettinger, U., Dreibus, M., Kerl-Wienecke, A., Wulff, P., Mechthild, P. \& Thaiss, H. (2018). Improving psychosocial services for vulnerable families with young children: strengthening 
links between health and social services in Germany. BMJ, 363, k4786. https://doi.org/10.1136/bmj.k4786

Rudkjøbing, A., Strandberg-Larsen, M., Vrangbaek, K., Andersen, J. S., \& Krasnik, A. (2014). Health care agreements as a tool for coordinating health and social services. International journal of integrated care, 14, e036. https://doi.org/10.5334/ijic. 1452

Scambler, G. (2002). Health and social change: A critical theory. Buckingham, UK: Open University Press.

Smith, C., \& Elger, T. (2014). Critical realism and interviewing subjects. In P. K. Edwards, J. O'Mahoney \& S. Vincent (Eds.), Studying organizations using critical realism: a practical guide (pp. 109-131). Oxford, UK: Oxford University Press. https://doi.org/10.1093/acprof:oso/9780199665525.003.0006

Sayer, A. (1992). Method in social science: a realist approach. London, UK: Routledge.

Star, S. L. (1988). The structure of ill-structured solutions: boundary objects and heterogeneous distributed problem solving. In M. Huhns \& L. Gasser (Eds.), Readings in distributed artificial intelligence. Menlo Park, CA: Kaufman. https://doi.org/10.1016/B978-1-55860-092-8.50006-X

Star, S. L., \& Griesemer, J. R. (1989). Institutional ecology, 'translations' and boundary objects: amateurs and professionals in Berkeley's Museum of Vertebrate Zoology, 1907-39. Social Studies of Science, 19, 387-420. https://doi.org/10.1177/030631289019003001

Timmermans, S., \& Tavory, I. (2012). Theory construction in qualitative research: from grounded theory to abductive analysis. Sociological Theory, 30, 167-186. https://doi.org/10.1177/0735275112457914

Titmuss, R. (1974). What is social policy?. In B. A. Smith \& K. Titmuss (Eds.), Social policy: an introduction. London, UK: Allen and Unwin.

Vabo, S. I. (2010). Actors and governance arrangements in long-term care for older people. In Y. Kazepov (Ed.), Rescaling social policies: towards multilevel governance in Europe (pp. 343-364). Surrey, UK: Ashgate. https://doi.org/10.4324/9781315244433-10

Vabo, S. I. (2014). Flernivåorganisering-lokal skreddersøm og nasjonale standarder [Multi-level governance-local tailoring and national standards]. In M. Vabø \& S. I. Vabo (Eds.), Velferdens organisering (pp. 158-174). Oslo, Norway: Universitetsforlaget.

Vabø, M., \& Szebehely, M. (2012). A caring state for older people? In A. Antonnen, L. Häikiö \& K. Stefánsson (Eds.), Welfare state, universalism and diversity (pp. 121143). Cheltenham, UK: Edward Elgar.

Valset, K. (2018). Investigating the link between school performance, aftercare and educational outcome among youth ageing out of foster care: a Norwegian nationwide longitudinal cohort study. Nordic Social Work Research. 8(1):79-93. https://doi.org/10.1080/2156857X.2018.1457557

Vike, H. (2018). Politics and bureaucracy in the Norwegian welfare state: an anthropological approach. Basingstoke, UK: Palgrave Macmillan. https://doi.org/10.1007/978-3-319-64137-9

Weber, M. (1971). Makt og byråkrati: essays om politikk og klasse, samfunnsforskning og verdier [Power and bureaucracy: Essays on politics and class, social research and values]. Oslo, Norway: Gyldendal. 
Wilks, T. (2004). The use of vignettes in qualitative research into social work values. Qualitative Social Work, 3, 78-87. https://doi.org/10.1177/1473325004041133

Øverbye, E. (2018). Er selektivisme bedre enn universalisme i velferdspolitikken? [Is selectivism better than universalism?] Norsk sosiologisk tidsskrift, 2(1). https://doi.org/10.18261/issn.2535-2512-2018-01-04 